\title{
PENGEMBANGAN MEDIA OTAK KATA TEMA PERTANIAN BAGI SISWA KELAS III SEKOLAH DASAR
}

\author{
Titik Murdhiyaningsih*, Fine Reffiane, Iin Purnamasari \\ Pendidikan Guru Sekolah Dasar-UPGRIS
}

\begin{abstract}
This research is motivated by learning that still tends to use lecture method. Based on needs analysis at seven schools have not provided media and are in desperate need of media. The purpose of this research is to know the validity of Word Brain Media (MEDOKA) and to know the practicality of using Word Brain Media (MEDOKA) on Agricultural Class III Primary School theme. The subjects of this study were Class III State Elementary School Ngablak 01 as the product trial class with the number of 30 students using large groups and small groups, and Class III State Elementary School Ngablak 02 as a class trial product with the number of students 17. Research method used is Research and Development or development research using ADDIE (Analysis, Design, Development, Implementation, and Evaluation). The result of the analysis on the material expert's validation was $86,7 \%$, two media experts $98,3 \%$, the questionnaire of SD Negeri Ngablak $0188,46 \%$, SD Negeri Ngablak 02 69,29\%, questionnaire of teacher of State Element Ngablak 01 86,6\% and SD Negeri Ngablak 02 69.23\%. Demonstrate MEDOKA is valid and practical in the theme of agricultural energy materials. The conclusion of this research is the development of practical and valid MEDOKA as the motivation, interest, and effectiveness of the students of Primary Class III. MEDOKA is used for new learning media.
\end{abstract}

Key word: R\&D; ADDIE; \& MEDOKA, agriculture

\begin{abstract}
Abstrak:Penelitian ini dilatarbelakangi oleh pembelajaran yang masih cenderung menggunakan metode ceramah. Berdasarkan analisis kebutuhan pada tujuh sekolah belum menyediakan media dan sangat membutuhkan media. Tujuan dari penelitian ini adalah mengetahui validitas Media Otak Kata (MEDOKA) dan, mengetahui kepraktisan penggunaan Media Otak Kata (MEDOKA) pada Tema Pertanian kelas III Sekolah Dasar. Subjek penelitian ini adalah Kelas III SD Negeri Ngablak 01 sebagai kelas uji coba produk dengan jumlah siswa 30 menggunakan kelompok besar dan kelompok kecil, serta Kelas III SD Negeri Ngablak 02 sebagai kelas uji coba produk dengan jumlah siswa 17. Metode penelitian yang digunakan adalah Research and Development atau penelitian pengembangan menggunakan ADDIE (Analysis, Design, Development, Implementation, and Evaluation). Hasil analisis pada validasi ahli materi $86,7 \%$, dua ahli media 98,3\% , angket tanggapan SD Negeri Ngablak 01 88,46\%, SD
\end{abstract}


Negeri Ngablak 02 69,29\%, angket guru SD Negeri Ngablak 01 86,6\% dan SD Negeri Ngablak 02 69,23\%. Menunjukkan MEDOKA valid dan praktis dalam tema pertanian materi energi. Kesimpulan penelitian ini adalah pengembangan MEDOKA praktis dan valid sebagai motivasi, minat, dan keefektifan belajar siswa SD Kelas III. MEDOKA digunakan untuk media pembelajaran yang baru.

Kata Kunci: R\&D; ADDIE; MEDOKA, pertanian

\section{PENDAHULUAN}

Kegiatan belajar dapat dikatakan berhasil apabila terjadi perubahan tingkah laku pada siswa. Perubahan tingkah laku tersebut dapat terjadi jika selama belajar siswa melakukan aktivitas berupa aktivitas fisik, mental dan emosional. Dalam undang-undang, yang dimaksud pendidikan yaitu:

"Pendidikan adalah usaha sadar dan terencana untuk mewujudkan suasana belajar dan proses pembelajaran agar peserta didik secara aktif mengembangkan potensi dirinya untuk memiliki kekuatan spiritual keagamaan, pengendalian diri, kepribadian, kecerdasan, dan akhlak mulia, serta ketrampilan yang diperlukan dirinya, masyarakat, bangsa dan negara (Sikdiknas, 2008: 3)”.

\begin{tabular}{lccc}
\multicolumn{2}{c}{ Pendidikan } & tidak & hanya \\
melibatkan & siswa & tetapi & banyak \\
melibatkan guru, metode, & tujuan, \\
kurikulum, media, sarana, & kepala
\end{tabular}

sekolah, pemerintah, masyarakat, penggunaan kelulusan, dan lingkungan fisik. Undang-Undang Nomor 20 tahun 2003 tentang Sistem Pendidikan Nasional Bab VI pasal 17 ayat 1 menyebutkan bahwa "pendidikan dasar merupakan jenjang pendidikan yang melandasi pendidikan jenjang menengah". Dari isi UU tersebut berarti bahwa pendidikan di sekolah dasar merupakan jenjang pendidikan yang sangat penting dan menentukan, karena pendidikan di sekolah dasar merupakan landasan pertama untuk menanamkan suatu konsep yang benar kepada anak. Pendidikan yang ada sekarang ini guru diberlakukan sebaik mungkin agar bisa membuat media yang akan dibelajarkan kepada siswa dalam proses pembelajaran. Kurikulum yang sering dirubah membuat siswa menjadi bingung(Hajar,2013).

Media pembelajaran sangat penting digunakan dalam proses belajar mengajar. Saat di kelas siswa cenderung 
bicara sendiri dan bermain dengan teman sebangkunya (Siregar dan Hartini 2011). Konsep belajar mengajar yang diberikan guru terhadap siswanya masih kurang menjadikan siswa kurang antusias. Proses pembelajaran harus didukung dengan media yang menarik agar siswa aktif dan tidak mudah bosan. Hal tersebut dikarenakan media merupakan perantara atau pengantar terjadinya komunikasi yang baik dan menyenangkan antara guru dan siswa (Daryanto, 2014) .

Persoalan motivasi dalam belajar juga sering ditemukan di dalam proses belajar mengajar. Menurut Sardiman (2014: 85) "motivasi sebagai pendorong usaha pencapaian prestasi". Seperti pembelajaran yang terjadi di kelas III Sekolah Dasar. Pada saat peneliti melakukan observasi di SD, belum menghasilkan pembelajaran yang aktif dan efektif. Hal ini secara tidak langsung juga sangat berpengaruh terhadap proses pembelajaran yang ada di sekolah. Menurut Sudharto, dkk (2012: 6) "pendidikan adalah usaha sadar dan terencana untuk mewujudkan suasana belajar dan proses pembelajaran agar siswa secara aktif mengembangkan potensi dirinya untuk memiliki kekuatan spiritual keagamaan, pengendalian diri kepribadian, kecerdasan, akhlak mulia, serta ketrampilan yang ditentukan oleh dirinya, masyarakat, bangsa dan negara". Pendidikan terlaksana dengan baik dan media pembelajaran dapat digunakan untuk memudahkan guru dalam proses belajar mengajar.

Media yang akan digunakan dibuat semenarik mungkin sehingga siswa mampu mengikuti pembelajaran dengan antusias dan semangat. Media yang menarik dapat digunakan guru untuk menjelaskan materi yang akan diajarkan kepada siswanya. Disitulah tolak ukur keberhasilan seorang guru dalam menyampaikan materi kepada siswa sesuai dengan tujuan yang diharapkan. Guru tidak harus menggunakan media yang mahal tetapi dapat menggunakan media dengan alat yang murah, sederhana dan efisien. Meskipun alat yang digunakan sederhana, tetapi tetap dapat mencapai tujuan pengajaran yang maksimal. Selain itu, guru juga dapat terus mengembangkan keterampilan membuat media pembelajaran yang akan digunakan dalam proses belajar. 


\section{METODE PENELITIAN}

Penelitian ini, menggunakan metode pengembangan atau Research and Development (R\&D). "Metode Penelitian dan pengembangan atau dalam bahasa Inggrisnya Research and Development adalah metode penelitian yang digunakan untuk menghasilkan produk tertentu, dan menguji keefektifan produk tersebut"(Sugiyono, 2010: 407). Menurut Sukmadinata (2015: 164) Research and Development ( $\mathrm{R} \& \mathrm{D})$ adalah suatu proses atau langkah untuk mengembangkan suatu produk baru atau menyempurnakan produk yang telah ada, yang dapat dipertanggungjawabkan (Putra,2015:34). Studi pendahuluan merupakan langkah awal dalam model ADDIE yaitu analisis. Penulis menganalisis permasalahan yang dihadapi dalam dunia pendidikan kemudian menentukan pemecahan masalah bagi seorang guru yang masih ada kendala dalam proses pembelajaran (Kadir,2014).

Jenis penelitian ini dipilih karena mengembangkan sebuah produk menjadi media pembelajaran. Media ini dikembangkan dari media buku dan diinovasikan menjadi Buku Otak Kata (MEDOKA) yang dapat meningkatkan motivasi, keaktifan, serta kreatifitas siswa dalam mencapai proses pembelajaran SD kelas III pada tema pertanian. Desain MEDOKA ini menggunakan prosedur penelitian $A D$ DIE yang dikemukakan oleh Pribadi (2010: 125-137) yang terdiri dari lima fase yaitu (1) Analysis, mengidentifikasi kebutuhan sekolah sehingga ditemukan masalah serta mencari solusi yang tepat untuk memecahkan masalah, (2) Design, untuk menentukan pemilihan media yang sesuai dengan SK dan $\mathrm{KD}$, merancang media yang akan dibuat memilih dan menentukan alat dan bahan, dan membuat desain media yaitu MEDOKA secara utuh, kemudian yang terakhir adalah membuat RPP untuk proses pembelajaran, (3) Development, untuk menetapkan tujuan pengembangan, dan pengujian oleh validator ahli media dan ahli materi, (4) Implementation, melaksanakan kegiatan pembelajaran dengan menggunakan MEDOKA dengan menerapkan desain atau spesifi- 
kasi media pembelajaran, (5) Evaluation, melakukan evaluasi proses pembelajaran dan evaluasi hasil belajar dengan memberikan angket tanggapan siswa terhadap MEDOKA (Mufarr okah,2009)

\section{PEMBAHASAN}

MEDOKA dikembangkan berdasarkan langkah-langkah $\mathrm{R} \& \mathrm{D}$ dengan metode penelitian dan pengembangan. Metode yang digunakan untuk menghasilkan produk tertentu dan menguji kelayakan produk tersebut. Prosedur pengembangan MEDOKA yaitu menggunakan ADDIE yaitu analysis, design, development, implementation, evaluation (Pribadi, 2010: 125). Media Otak Kata ini dikembangkan dengan menghasilkan produk berupa media pembelajaran yang menyenangkan. Dalam MEDOKA ini dikembangkan indikator pencapaian kompetensi berdasarkan masing-masing kompetensi dasar mata pelajaran yang terdapat dalam tema pertanian dengan materi energi. Hal ini, bertujuan agar produk media pembelajaran mampu mencakup indikator pada masing-masing kompetensi dasar yang akan dicapai.
Melihat karakteristik siswa SD kelas III yang banyak menyukai permainan dan bicara sendiri, maka penulis mengembangakan sebuah media permainan yang dapat digunakan dalam proses pembelajaran yang terbuat dari kertas art paper dan yellow board yang mudah didapat. Media Otak Kata merupakan media yang berbentuk seperti puzzle dan pop-up. MEDOKA dikembangkan dengan menetapkan tujuan pengembangan, mengidentifikasi standar kompetensi dan kompetensi dasar, serta membuat indikator untuk setiap kompetensi dasar sehingga membuat sebuah media. MEDOKA yang dikembangkan menggunakan desain, warna dan konsep yang menarik sehingga mampu menciptakan suatu media pembelajaran yang mampu menarik motivasi belajar, mampu menciptakan pembelajaran yang aktif dan menyenangkan bagi siswa.

Pengembangan MEDOKA untuk meningkatkan motivasi dan minat belajar siswa, karena MEDOKA mampu menarik perhatian siswa dan menunjang terjadinya pembelajaran yang aktif, kreatif dan menyenangkan bagi siswa. Produk yang dihasilkan dalam penelitian 
dan pengembangan ini berupa perangkat pembelajaran dan MEDOKA yang diharapkan layak diguanakan dalam pembelajaran. Selanjutnya peneliti mengujicobakan produk di SD Negeri Ngablak 01 dan SD Negeri Ngablak 02 untuk mengetahui hasil penilaian tanggapan guru dan siswa di sekolah.

Pengembangan yang dilakukan mengunakan ADDIE diperoleh hasil sebagai berikut :

\section{Analisis}

Analisis merupakan langkah pertama yang harus dilakukan. Langkah analisis terdiri atas dua tahap, yaitu:

\section{(1)Analisis kinerja (performance analysis)}

Tahap pertama ini yang dilakukan mencari tahu suatu permasalahan yang membutuhkan solusi berkaitan dengan kinerja dalam pembelajaran dapat berupa manajemennya atau pada program pembelajarannya.

(2)Tahap dua atau analisis kebutuhan (need analysis)

Langkah yang diperlukan untuk menentukan kemampuan-kemam- puan atau kompetensi yang perlu dipelajari oleh siswa untuk meningkatkan kinerja atau prestasi belajar (Pribadi, 2010: 128). Tahap analisis kebutuhan menentukan kemampuan siswa untuk meningkatkan motivasi dan juga meningkatkan kinerja seorang guru dalam meningkatkan kualitas sebagai guru profesional. Memotivasi dalam pengunaan media sangat dibutuhkan oleh guru maupun siswa. Pemakaian media pembelajaran dalam proses belajar mengajar dapat membangkitkan keinginan dan minat yang baru, membangkitkan motivasi dan rangsangan kegiatan belajar, dan bahkan membawa pengaruhpengaruh psikologis terhadap siswa (Hamalik dalam Arsyad, 2013: 19).

Analisis kebutuhan sekolah yang dilakukan terhadap tujuh sekolah dasar yang ada di Kecamatan Cluwak Kabupaten Pati melalui pengisian angket guru. Ditemukan berbagai permasalahan bahwa sekolah membutuhkan media pembelajaran alternatif dalam proses belajar mengajar berupa video, gambar, buku bergambar ataupun permainan. 
Selain itu, penulis melakukan observasi dan wawancara tidak terstruktur dengan guru kelas ketika magang di Sekolah Dasar, siswa kelas III SD lebih suka bermain daripada belajar. Masa-masa bermain mulai dari TK sampai kelas II masih terbawa sampai di kelas III.

Konsentrasi siswa pada pembelajaran tidak sampai setengah jam pelajaran mulai dari awal materi sampai selesai. Siswa sering melakukan hal-hal yang membuat ramai. Tidak fokus terhadap apa yang dijelaskan oleh guru di depan kelas. Sering kali guru menggunakan media dan metode pembelajaran yang dianggap belum menarik perhatian siswa. Karena siswa tidak disuguhi dengan adanya permainan di dalamnya. Terkadang siswa tidak terlibat langsung dalam proses pembelajaran yamg ada di dalam kelas. Guru dalam menerangkan sering kali menggunakan buku pelajaran seadanya tanpa mengembangkannya sesuai dengan karakteristik siswa.

Anak malas belajar dan malas mendengarkan guru saat kegiatan belajar mengajar berlangsung. Akibatnya, sering kali anak tidak memperhatikan guru dan dalam pelajaran, ribut sendiri, dan bahkan ada yang tidak mau duduk. Berdasarkan observasi dan wawancara tidak terstruktur yang dilakukan oleh penulis, dapat menjadi landasan sebagai pengembangan Media Otak Kata (MEDOKA) yang dapat digunakan sebagai salah satu alternatif untuk mengajarkan materi kepada siswa supaya pembelajaran lebih efektif dan aktif.

Studi pendahuluan yang dilakukan oleh penulis yaitu dengan analisis kebutuhan sekolah melalui pengisian angket yang dilakukan ke tujuh sekolah dasar, wawancara tidak terstruktur dengan guru kelas, dan melalui observasi tidak terstruktur yang dilakukan pada tujuh sekolah dasar yang terdapat di Kecamatan Cluwak Kabupaten Pati. Hasil angket analisis kebutuhan sekolah sebagai berikut: $85,71 \%$ pembelajaran pada tema pertanian yang dilakukan oleh Bapak/ibu guru sudah sesuai dengan kompetensi dan $14,28 \%$ menyatakan belum sesuai; $85,71 \%$ pembelajaran 
pada tema pertanian sudah menyenangkan bagi siswa dan $14,28 \%$ menyatakan belum menyenangkan; 85,71\% Bapak/ibu guru memiliki koleksi media pembelajaran untuk mengajarkan tema pertanian dan $14,28 \%$ tidak memiliki koleksi media pembelajaran; $57,14 \%$ dalam pembelajaran tema pertanian mengalami kendala dalam memilih media yang menyenangkan bagi siswa dan $42,85 \%$ tidak mengalami kendala dalam memilih media; $100 \%$ pada tema pertanian memerlukan media pembelajaran alternatif yang sesuai dengan karakteristik siswa;

Selanjutnya Bentuk media pembelajaran yang disukai siswa kelas III Sekolah Dasar meliputi permainan $57,14 \%$, gambar $57,14 \%$, buku bergambar 57,14\%, video $28,57 \%$, dan bentuk lainnya $28,57 \%$; $100 \%$ Bapak/ibu guru pernah mengajarkan tema pertanian menggunakan media pembelajaran buku bergambar; $85,71 \%$ bentuk permainan yang membongkar pasang gambar dan kata sesuai dengan karakteristik siswa kelas III Sekolah
Dasar dan 14,28\% tidak sesuai dengan karakteristik siswa; Bahan yang dibutuhkan dalam pembuatan media dalam pembelajaran tema pertanian dalam bentuk permanen $85,71 \%$ dan sekali pakai $42,85 \%$; 100\% Bapak/ibu guru belum pernah melihat Media Otak Kata (MEDOKA) dan belum pernah menggunakannya dalam pembelajaran tema pertanian( Kasmoyo, ,dkk, 2015).

\section{Desain}

Hasil dari analisis kebutuhan tersebut dapat digunakan peneliti sebagai landasan untuk merancang suatu media pembelajaran yang mengaktifkan siswa, mengasah otak siswa, membuat suasana belajar yang menyenangkan dan tidak membosankan. Penulis akan mengembangkan media pembelajaran dalam permainan dengan tujuan mengarahkan gaya bermain positif sehingga siswa dapat tertarik dan termotivasi dalam pembelajaran. Media Otak Kata (MEDOKA) merupakan rancangan peneliti dalam pembuatan media pembelajaran yang menarik dengan bermain sambil belajar yang menjadikan 
anak lebih kreatif dan aktif (Sardiman, 2014 ).

Setelah melakukan kegiatan analisis, akan dilanjutkan dengan desain. Desain ini merupakan langkah untuk merancang suatu produk, sehingga produk yang dihasilkan sesuai dengan tujuan pembelajaran yang akan dilaksanakan. Menurut Pribadi (2010: 130) "langkah terpenting yang perlu dilakukan dalam desain adalah menentukan pengalaman belajar atau learning experience yang perlu dimiliki oleh siswa selama mengikuti aktivitas pembelajaran". Dari pengalaman siswa terhadap analisis kebutuhan, siswa perlu adanya rancangan media pembelajaran. Desain harus mampu mendukung tercapainya media pembelajaran yang efektif. Sehingga hasil analisis tentang kebutuhan siswa diatas dapat digunakan sebagai landasan untuk merancang media pembelajaran. Salah satu media alternatif yang akan dirancang adalah Media Otak Kata (MEDOKA) yang didesain untuk menjelaskan tentang tema pertanian materi energi kelas III sekolah dasar.

\section{Pengembangan}

Menurut Pribadi (2010: 132) langkah pengembangan meliputi kegitan membuat, membeli, dan modifikasi bahan ajar atau learning materials untuk mencapai tujuan pembelajaran yang telah ditentukan. Dengan kata lain, langkah ini mencakup kegiatan mengembangkan atau memilih media agar menunjang tercapainya tujuan dari pembelajaran. Langkah menentukan media disesuaikan dengan materi pembelajaran yang ada, kemudian dari kebutuhan yang mendukung materi tersebut dikembangkan menjadi media. MEDOKA menjadi sebuah patokan pengembangan untuk mengembangkan suatu media yang diadaptasi dari sebuah buku yang dapat dibongkar pasang dan banyak disukai siswa. MEDOKA juga menjadi sebuah media pembelajaran yang menarik, menyenangkan, dan mampu memudahkan dalam penyampaian materi.

Penelitian dan pengembangan MEDOKA belum pernah dilakukan sebelumnya.

Pengembangan MEDOKA baru dikembangkan oleh penulis. Media Otak Kata (MEDOKA) dikemas berbentuk buku dengan ukuran A4 seperti media pop-up yang 
dapat dibongkar pasang seperti media puzzle. Tetapi yang menjadi perbedaan dengan pengembangan Media Otak Kata (MEDOKA) dengan media popup dan puzzel terletak pada bentuk, kualitas bahan, kelengkapan materi, dan terdapat permainan di dalamnya. Maka penulis membuat pengembangan media yang baru dan lebih menarik. Berikut langkah-langkah dalam menentukan pengembangan Media Otak Kata (MEDOKA) tersebut yaitu:
1) Menentukan tujuan pengem- bangan

Tujuan pengembangan media pembelajaran MEDOKA adalah untuk memudahkan pemahaman siswa dalam mempelajari tema pertanian materi energi pada kelas III sekolah dasar (Kustandi,2013).

2) Mengidentifikasi Standar Kompetensi dan Kompetensi Dasar

Kurikulum Tingkat Satuan Pendidikan (KTSP) pada kelas rendah masih menggunakan pembelajaran tematik. KTSP sudah menyajikan silabus dengan memuat tema yang akan diajarkan (Rohman, Hifni. 2011).

3) Menyusun desain Media Otak Kata (MEDOKA)
Desain dibuat berdasarkan pengembangan penelitian yang belum ada, penulis mengembangkan Media Otak Kata (MEDOKA) dalam pembelajaran KTSP Tematik sesuai dengan kebutuhan dan karakteritik siswa kelas III Sekolah Dasar. Model yang dibuat berbentuk visual. Dimana dibuat berbentuk seperti buku yang bisa dibongkar pasang seperti puzzle. Media pembelajaran cocok untuk mengatasi masalah, kemudian disiapkan setelah mengidentifikasi masalah. Tahapan dimulai menyusun desain media pembelajaran MEDOKA yang meliputi penyusunan pokok materi, penyusunan naskah secara keseluruhan, pembuatan media Sadiman, (Arief S. dkk, 2011). Perancangan MEDOKA dapat dilihat sebagai Membuat rancangan model MEDOKA pada Gambar 1.

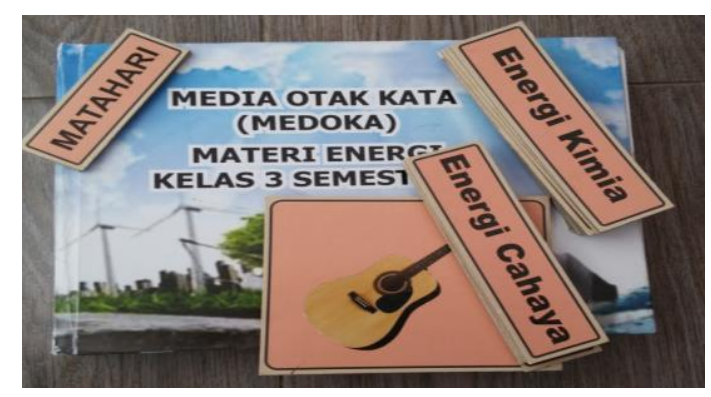




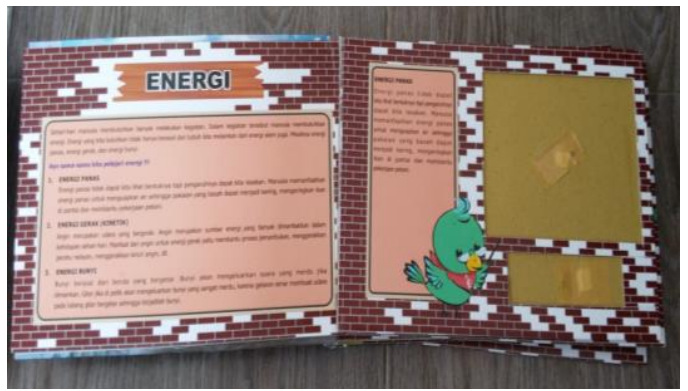

Gambar 1 Media Otak Kata

\section{Validasi}

Desain MEDOKA divalidasi terlebih dahulu.Validasi atau uji validitas sangat penting dilakukan untuk menguji produk atau desain yang dikembangkan layak atau tidak jika diterapkan untuk pembelajaran. Uji validitas yang dilakukan peneliti meliputi validasi ahli materi dan validasi ahli media yang berkompeten dibidangnya. Validasi MEDOKA dilakukan oleh validator ahli materi dan media sebanyak dua kali. Media yang sudah divalidasi kemudian diperbaiki sesuai dengan saran dan masukan dari para ahli. MEDOKA selanjutnya dibuat dalam bentuk media yang sesuai dengan materi (Majid,2014).

MEDOKA dikatakan valid dapat dilihat dari persentase hasil uji ahli media dan ahli materi terhadap MEDOKA. Penilaian yang dilakukan oleh ahli media dalam setiap validasi dapat diketahui rata-rata persentase keidealannya. Berdasarkan rata-rata penilaian ahli media dari keseluruhan aspek yang dilakukan dosen, maka akan diperoleh hasil rata-rata penilaian dari semua ahli media. Rata-rata penilaian MEDOKA oleh semua ahli media yaitu sebesar 98,3\%, sehingga berdasarkan penilaian ahli media MEDOKA termasuk dalam kriteria "Sangat Layak Digunakan".

Penilaian yang dilakukan oleh ahli materi dalam setiap validasi dapat diketahui rata-rata persentase keidealannya. Berdasarkan rata-rata penilaian ahli materi dari keseluruhan aspek yang dilakukan dosen, maka akan diperoleh hasil rata-rata penilaian dari semua ahli materi. Rata-rata penilaian MEDOKA oleh semua ahli materi yaitu sebesar $86,7 \%$, sehingga berdasarkan penilaian ahli materi MEDOKA termasuk dalam kriteria "Sangat Layak Digunakan". Rata-rata penilaian yang dilakukan oleh ahli media terhadap MEDOKA memiliki persentase keidealan sebesar 98,3\% dengan kriteria "Sangat Layak Digunakan". Rata-rata penilaian yang dilakukan oleh ahli materi memiliki 
persentase keidealan sebesar 86,7\% dengan kriteria "Sangat Layak Digunakan". Sehingga berdasarkan penilaian pada uji ahli media dan uji ahli materi, pengembangan MEDOKA berhasil atau valid digunakan pada tema pertanian kelas III Sekolah Dasar (Pramesti, Jatu. 2015).

\section{Implementasi}

Pengembangan media Otak Kata (MEDOKA) berdasarkan kebutuhan siswa kelas III Sekolah Dasar. Sebelum uji coba di sekolah, MEDOKA akan divalidasi terlebih dahulu. Uji validasi meliputi ahli materi dan ahli media. Uji validasi bertujuan untuk mendapatkan desain media Otak Kata (MEDOKA) yang sempurna. Media Otak Kata (MEDOKA) yang sudah sesuai dengan validasi ahli media dan ahli materi selanjutnya diterapkan pada kelas ujicoba.

Setelah desain produk, menurut Sugiyono (2010: 414) “divalidasi melalui diskusi dengan pakar dan para ahli lainnya, maka akan diketahui kelemahanya. Kelemahan tersebut selanjutnya dicoba untuk dikurangi dengan cara memperbaiki desain. Yang bertugas memperbaiki desain adalah penulis yang akan menghasilkan produk tersebut". Setelah MEDOKA dikatakan valid oleh ahli media dan ahli materi, selanjutnya dilakukan uji coba skala terbatas pada seluruh siswa kelas III SD Negeri Ngablak 01 dan SD Negeri Ngablak 02. Di Kecamatan Cluwak Kabupaten Pati.

Pada tahapan implementasi, bertujuan untuk mendapatkan hasil desain media pembelajaran yang valid, praktis, dan baik. Revisi produk dilakukan oleh penulis secara berkala, apabila desain belum mencapai tingkatan yang valid dan sesuai yang diharapkan. Pihak yang berperan penting pada tahap ini adalah ahli media pembelajaran dan ahli materi pembelajaran yang menentukan apakah desain memerlukan revisi atau sudah selesai. Setelah Media Otak Kata (MEDOKA) sudah direvisi dan diperbaiki, maka media pembelajaran Media Otak Kata (MEDOKA) sudah siap diuji kepada kelas dengan uji coba skala terbatas. 


\section{Evaluasi}

Langkah terakhir pada model ADDIE ini yaitu evaluasi, dimana evaluasi ini merupakan suatu proses yang dilakukan sehingga ada penilaian terhadap proses program pembelajaran. Sebenarnya, evaluasi dapat dilakukan pada tiap lima langkah pembelajaran. Evaluasi dapat dilakukan dengan cara mengklarifikasi suatu tujuan pembelajaran yang dicapai berdasarkan pengetahuan siswa, keterampilan siswa, dan juga pada sikap siswa pada saat proses pembelajaran.

Dilakukan evaluasi untuk Media Otak Kata (MEDOKA) yang bertujuan menyempurnakan produk setelah melalui tahap implementasi. Evaluasi meliputi perbaikan produk yang didapat dari saran pada angket yang diberikan kepada ahli media, ahli materi dosen Universitas PGRI Semarang. Selanjutnya MEDOKA tersebut dapat diperbaiki dan disempurnakan oleh penulis (Sanaky, Hujair AH. 2013). Efektif atau tidaknya MEDOKA serta minat siswa terhadap media tersebut dapat dilihat dari angket tanggapan siswa(Ensa:2015).
Hasil tanggapan guru dan siswa terhadap MEDOKA juga dihitung ratarata persentase keidealanya untuk mengetahui kepraktisan MEDOKA. Tanggapan guru kelas III terhadap MEDOKA yang dilakukan oleh ibu Dewi Yuliati, S.Pd dari SD Negeri Ngablak 01 dan bapak Biyanto dari SD Ngablak 02 akan diperoleh rata-rata persentase keidealan. Diketahui ratarata persentase keidealan tanggapan guru terhadap media MEDOKA. Berdasarkan rata-rata persentase keidealan hasil tanggapan setiap guru terhadap MEDOKA pada keseluruhan indikator, maka akan diperoleh rata-rata persentase keidealan hasil tanggapan semua guru terhadap MEDOKA. Rata-rata persentase keidealan hasil tanggapan semua guru terhadap MEDOKA yaitu sebesar 77,9\%, sehingga berdasarkan tanggapan guru melalui lembar angket tanggapan guru terhadap MEDOKA termasuk dalam kriteria "Layak Digunakan".

Tanggapan siswa kelas III terhadap MEDOKA dilakukan oleh seluruh siswa kelas III SD Ngablak 01 dengan jumlah 30 siswa dan seluruh siswa kelas III SD Negeri Ngablak 02 
dengan jumlah siswa 17. Selanjutnya akan diperoleh rata-rata persentase keidealan dari penilaian keseluruhan soal. Akan diketahui rata-rata persentase keidealan tanggapan siswa terhadap MEDOKA. Berdasarkan ratarata persentase keidealan hasil tanggapan siswa dari setiap sekolah terhadap MEDOKA pada keseluruhan soal, maka akan diperoleh rata-rata persentase keidealan hasil tanggapan semua siswa dari ketiga sekolahan tersebut terhadap MEDOKA. Rata-rata persentase keidealan hasil tanggapan semua siswa terhadap MEDOKA yaitu sebesar 78,8\%, sehingga berdasarkan tanggapan siswa melalui lembar angket tanggapan siswa terhadap MEDOKA, Media Otak Kata termasuk dalam kriteria "Layak Digunakan".

Hasil rata-rata tanggapan guru terhadap MEDOKA memiliki persentase keidealan sebesar 77,9\% dengan kriteria "Layak Digunakan". Dan ratarata hasil tanggapan siswa terhadap MEDOKA memiliki persentase keidealan sebesar 78,8\% dengan kriteria "Layak Digunakan". Sehingga berdasarkan hasil tanggapan guru dan hasil tanggapan siswa terhadap
MEDOKA, maka pengembangan MEDOKA praktis digunakan pada tema pertanian kelas III Sekolah Dasar. (Sundayana, W. 2014)

MEDOKA mampu menarik perhatian dan menyalurkan pesan kepada siswa terhadap proses pembelajaran. Diketahui berdasarkan hasil angket tanggapan siswa dan hasil angket tanggapan guru. Sesuai dengan penggunaan media pembelajaran menurut Aqib (2015: 50) media pembelajaran adalah segala sesuatu yang dapat digunakan untuk menyalurkan pesan dan merangsang terjadinya proses belajar pada si pembelajaran (siswa).

\section{KESIMPULAN}

Berdasarkan hasil penelitian dan pembahasan pada penelitian pengembangan media maka dapat diambil simpulan bahwa Kevalidan MEDOKA dilakukan dengan cara melakukan validasi media dan materi pembelajaran kepada ahli media dan materi. Penilaian oleh ahli media yang dilakukan oleh dua dosen Universitas PGRI Semarang dengan rata-rata persentase keidealan 98,3\% dengan kriteria "Sangat Layak 
Digunakan". Penilaian oleh ahli materi yang dilakukan oleh dosen dan guru didapat rata-rata persentase keidealan 86,7\% dengan kriteria "sangat Layak Digunakan”. Sehingga pengembangan MEDOKA valid digunakan pada tema Pertanian materi Energi kelas III Sekolah Dasar.Kepraktisan MEDOKA dilakukan dengan cara memberikan angket tanggapan guru dan siswa kelas III SD Negeri Ngablak 01 dan SD Negeri Ngablak 02. Hasil tanggapan kedua guru dari dua sekolah tersebut diperoleh hasil rata-rata keidealan sebesar 77,9\% dengan kriteria "Layak Digunakan". Dan hasil tanggapan siswa kelas III dari dua sekolah dasar tersebut memiliki rata-rata persentase keidealan sebesar 78,8\% dengan kriteria "Layak Digunakan". Sehingga pengembangan MEDOKA praktis digunakan pada tema Pertanian materi Energi kelas III Sekolah Dasar.

\section{DAFTAR PUSTAKA}

Aqib, Zainal. 2015. Model-model, Media, dan Strategi Pembelajaran Kontekstual (Inovatif). Bandung: Yrama Widya.

Arsyad, Azhar. 2013. Media Pembelajaran. Jakarta : PT Raja Grafindo Persada.

Asyar, Rayandra. 2012. Kreatif Mengembangkan Media Pembelajaran. Jakarta : Refrensi Jakarta.

Ensa, Hikmatun Nisa. 2015. Pengembangan Media Puzzle Pada Konsep Pengukuran Bangun Datar Terhadap Pemahaman Siswa Kelas IV MI Al Mufidah Wongsorejo Banyuwangi. Skripsi. Malang: Universitas Islam Negeri Maulana Ibrahim Malang.

Daryanto. 2014. Pembelajaran Tematik, Terpadu, Terintegrasi (Kurikulum 2013). Yogyakarta : Gava Media.

Hajar, Ibnu. 2013. Panduan Kurikulum Tematik Untuk SD/MI. Jogjakarta : Diva Press.

Kadir, Abd dan Hanun Asrohah. 2014. Pembelajaran Tematik. Jakarta: PT. Raja Grafindo Persada.

Kustandi, Cecep dan Bambang Sutjipto. 2013. Media Pembelajaran Manual dan Digital. Bogor : Ghalia Indonesia.

Majid, Abdul. 2014. Pembelajaran Tematik Terpadu. Bandung: PT. Remaja Rosdakarya Mufarrokah, Anisatul. 2009. Strategi Belajar Mengajar. Yogyakarta : Teras. 
Putra, Nusa. 2013. Research and Development. Jakarta : PT Grafindo Persada.

Pramesti, Jatu. 2015. Pengembangan Media Pup-Up Book Tema Peristiwa Untuk Kelas III SD Negeri Pakem 1. Skripsi. Yogyakarta : Universitas Negeri Yogyakarta.

Pribadi, Benny A. 2010. Model Desain Sistem Pembelajaran. Jakarta : PT Dian Rakyat.

Kasmoyo, Ratna. (dkk). 2015. Penerapan Metode Demonstrasi Sebagai Upaya Peningkatan Hasil Belajar Siswa di Kelas III SDN Mire. Jurnal Kreatif Tadulako Online. Volume 5, Nomor 2.

Rohman, Hifni. 2011. Pengertian KTSP. Hipni.blogspot.com/2011/09/pengertianktsp.html?m=1. Diakses 3 November 2016.

Sadiman, Arief S. (dkk). 2011. Media Pendidikan. Jakarta : PT Raja Grafindo Persada.

Sanaky, Hujair AH. 2013. Media Pembelajaran Interaktif - Inovatif. Yogyakarta : Kaukaba Dipantara.

Sardiman. 2014. Interaksi \& Motivasi Belajar Mengajar. Jakarta : Rajawali Pers.

Siregar, Eveline dan Hartini Nara. 2011. Teori Belajar dan Pembelajaran. Bogor: PT. Ghalia Indonesia.

Sudharto, (dkk). 2012. Pengantar Ilmu Pendidikan. Semarang : FIP IKIP PGRI Semarang.

Sugiyono. 2010. Metode Penelitian Pendidikan (Pendekatan Kuantitatif, Kualitatif, $R \&$ $D)$. Bandung : Alfabeta.

Sukmadinata, Nana Syaodih. 2013. Metode Penelitian Pendidikan. Bandung : PT Remaja Rosdakarya.

Sundayana, Wachyu. 2014. Pembelajaran Berbasis Tema. Jakarta : PT. Gelora Aksara Pratama.

UU No. 20 tahun 2003. 2008. Sistem Pendidikan Nasional. Jakarta : Sinar Grafika.

Wikipedia. 2016. Kurikulum Tingkat Satuan Pendidikan. https://id.m.wikipedia.org/wiki/Kurikulum_Tingkat_Satuan_Pendidikan. Diakses 3 November 2016. 